Article

\title{
Executive Gender and Firm Environmental Management: Evidence from CFO Transitions
}

\author{
Bo Wang ${ }^{1}$, Zehui Wang ${ }^{2}$, Jun Wen ${ }^{3}$ and Xiaotian Tina Zhang ${ }^{4, *}$ \\ 1 Stuart School of Business, Illinois Institute of Technology, Chicago, IL 60661, USA; bwang54@hawk.iit.edu \\ 2 Software College of Northeastern University, Shenyang 110169, China; 20195379@stu.neu.edu.cn \\ 3 School of Economics and Finance, Xi'an Jiaotong University, Xi'an 710049, China; wjun1978@163.com \\ 4 Department of Finance, School of Economics and Business Administration, Saint Mary's College of California, \\ Moraga, CA 94556, USA \\ * Correspondence: xz4@stmarys-ca.edu
}

check for updates

Citation: Wang, B.; Wang, Z.; Wen, J.; Zhang, X.T. Executive Gender and Firm Environmental Management: Evidence from CFO Transitions. Sustainability 2021, 13, 3653. https:// doi.org/10.3390/su13073653

Academic Editor: Ştefan

Cristian Gherghina

Received: 19 February 2021

Accepted: 18 March 2021

Published: 25 March 2021

Publisher's Note: MDPI stays neutral with regard to jurisdictional claims in published maps and institutional affiliations.

Copyright: (c) 2021 by the authors. Licensee MDPI, Basel, Switzerland. This article is an open access article distributed under the terms and conditions of the Creative Commons Attribution (CC BY) license (https:// creativecommons.org/licenses/by/ $4.0 /)$.

\begin{abstract}
We investigate whether female executives influence corporate environmental management (green management). Based on a difference-in-difference approach, our study provides evidence that female CFOs conduct more environmentally responsible activities, and the effects are more prominent when firms are of high risks. Female CFOs are more likely to involve in environmental management voluntarily. Further, environmental management improves firm performance such as debt cost saving. This research advances the gender diversity literature and suggests that female executives play an important role in corporate decisions and firm performance.
\end{abstract}

Keywords: CFO; corporate social responsibilities; environmental management; executive gender; firm performance; female; green management

\section{Introduction}

Environmental management (green management) has gained significant popularity recently for practitioners, academics, and policymakers. With the rising recognition of environmental fragility and global warming concerns, firms pay close attention to environmentally responsible activities that go beyond the compliance of regulations and laws [1]. Failing to consider the influence of corporate environmental-related decisions brings more challenges in the financial market. Firms with environmental issues are found to experience a higher cost of capital due to potential regulatory, compliance, and litigation risks [2]. Socially responsible (green) investors clearly show preferences for sustainable firms; thus, polluting firms are more likely to be eschewed by such investors [3]. Meanwhile, active environmental management generates multiple benefits. For example, firms with responsible environmental performance are associated with better performance [4-6], higher resource efficiency [7], lower cost of capital [2,8,9] and larger stock returns [10].

Providing the broad benefits and potential misconduct costs, environmental management becomes a unique and critical strategy that enhances the firm's competitive advantages [11,12]. An emerging line of research emphasizes the critical role of executives in designing and implementing a firm's strategies (e.g., Benmelech and Frydman [13]; Bertrand and Schoar [14]; Lewis, Walls, and Dowell [15]). In this study, we intend to empirically investigate the relationship between corporate environmental management and executive gender.

Nowadays, CFOs are beyond the image of 'bean counter' and deeply involved in firms' accounting, financing, and investment decision-making [16,17]. CFOs are responsible for evaluating the costs and benefits before making decisions on how to allocate the firm's capital and resources to green activities. Gender diversity, as one of the fundamental demographic differences among executives, is identified as an essential determinant of corporate decision-making [18-20]. We compare whether and how female and male CFOs implement green management differently. 
We posit that gender differences may lead female CFOs to pay more attention to corporate environmental management for several reasons. First, psychology and finance literature has revealed that women have a higher risk aversion than men [21,22]. The upper echelons theory suggests that those preferences on risks will influence female $\mathrm{CFOs}^{\prime}$ choices and decisions $[23,24]$. Second, women are found to show more work ethics and sensitivity to ethical codes $[25,26]$. Therefore, female CFOs are more likely to follow environmental regulations and codes. Third, women demonstrate closeness to nature and the environment [27] and are expected to participate in more green behaviors [28,29].

To mitigate potential endogeneity concerns, we adopt a difference-in-difference (DID) approach in our analysis. We utilize the Compustat Execucomp database with 94 male-tofemale CFO transitions and 388 male-to-male CFO transitions in U.S. public firms between 2006 and 2015. Consistent with our expectation, we find that after the transition, firms with female CFOs significantly improve overall environmental performance compared to those with male CFOs post transitions.

If female CFOs are more risk-averse than male CFOs, the gender effects on environmental management will be stronger when a CFO belongs to a high-risk firm. We construct subsamples based on different measures of risks before the transition and find consistent results. Stakeholder value-maximization theory suggests that managers should balance the interests of all the stakeholders to maximize the firm value $[30,31]$. We adopt a quasi-natural experiment, the passage of state constituency statutes, which requires firm managers to consider the interest of all stakeholders when making decisions. Our results demonstrate that the executive gender effects on environmental management are stronger when one state does not pass the constituency statutes.

In addition, we examine the effects of environmental management on the cost of newly issued bonds. According to the stakeholder theory, better environmental management leads to lower firm risk, which permits the bondholder to require lower risk premiums. Using two measures of the cost of bonds, the bond yield spread and Standard \& Poor (S\&P) credit ratings, we find that overall environmental responsibility performance is negatively associated with yield spread and positively associated with credit ratings.

The remainder of our paper is structured as follows. In Section 2, we review previous literature and build our hypotheses. In Section 3, we introduce the data, sample, and measure construction. In Section 4, we present the empirical results and in Section 5 we conclude.

\section{Literature Review and Hypotheses Building}

Firms' decision-making process is associated with managerial traits and experiences, for instance, management style [14], executive's confidence level [32], education background [15], and early-life experience [13,33]. There is also evidence that executive gender, an essential demographics factor, impacts corporate decisions and policies (e.g., Cumming, Leung, and Rui [34]; Manner, [35]; Peni and Vähämaa [36]).

Gender difference literature has acknowledged that women are more risk-averse than men [21,22]. Early empirical evidence shows that females tend to allocate investments to less risky assets $[37,38]$. Olsen and Cox [39] suggest that professionally trained female investors weigh risk attributes more heavily than male peers do. Upper echelons theory suggests that executives' choices are made based on their personalized experiences, values, and personalities $[23,24]$. Therefore, the difference in risk aversion will be reflected in firm decisions. Huang and Kisgen [20] provide evidence that male executives are relatively overconfident and optimistic in making corporate decisions compared to female executives. Francis et al. [19] find that female CFOs are inversely associated with tax aggressiveness. Li and Zeng [40] show that there is a negative relationship between female CFOs and future stock price crash risk.

Researchers in psychology, ethics, and finance have noticed that women are more sensitive to ethicality [25]. Dawson [41] argues that, according to gender socialization theory, males and females demonstrate different work-related moral principles due to the 
masculine and feminine personalities formed in childhood. Mason and Mudrack [42] provide evidence that employed women show to be more ethical, which supports the gender socialization theory that women share communal values reflecting concerns for others, selflessness, and compassion. Regarding managers and executives, Ibrahim et al. [26] find that female managers are more sanguine and sensitive to the ethical codes. Xia et al. [43] find that female top managers are less likely to engage in corruption. As a result, female CFOs are expected to follow environmental regulations and codes and avoid activities that cause potential environmental concerns.

Furthermore, Wehrmeyer and McNeil [27] document a close relationship between females and the environment due to the female's reproductive nature. Women are more concerned about perceived environmental risks than men [28,44]. Thus, females are expected to express a higher level of concern and participate in more green behaviors than males [29].

Based on the identified differences in risk aversion, ethics, and nature closeness, we propose our first hypothesis, which is that female CFOs would pay more attention to corporate environmental management.

Hypothesis 1 (H1). Firms with female CFO conduct more environment management activities.

Since female CFOs are generally more risk-averse [21,22], we expect female CFOs would use green management to reduce the firm environment risks. Literature shows that improved corporate environmental performance is valued by the investors and helps reduce the cost of capital [9]. Thus, the effects of female CFOs on corporate environment performance shall be more prominent when firms are of high risks. We then present our second hypothesis as follows.

Hypothesis 2 (H2). Female CFOs from high-risk firms perform more environmental management activities.

Stakeholder theory posits that managers have to balance the interests of all the stakeholders to maximize the firm value [30,31]. Evidence shows that other stakeholders, such as institutional investors, assess firms' risks related to their environmental performance, including climate change risk and carbon emission control [45]. Environmentally responsible performance, along with other dimensions of corporate social responsibility (CSR), has been utilized in market valuation models [46,47]. Hence, firms' pro-environment activities will be valuable since such management mitigates corporate risks. Nielsen and Huse [48] point out that women may be involved more in issues that concern the firm and stakeholders, such as CSR and environmental politics, due to their consideration of the needs of others. Thus, we posit our next hypothesis:

Hypothesis 3 (H3). Female CFOs are more likely to conduct environmental management voluntarily.

There is extant evidence that environmental management brings significant benefits to firms. Firms with more environmental concerns and worse environmental profiles may be considered riskier by investors. Sharfman and Fernando [9] posit that improved environmental risk management mitigates the market's risk perception of the firm. Firms with fewer environmental concerns are more desirable by those green investors who are looking for socially responsible investments [3]. The strategic environmental investment could also help improve resource efficiency [7]. Jin et al. [8] demonstrate that environmental-friendly practices are associated with low bank loan costs and more favorable terms. Chava [2] provides evidence that the environmental profile of a firm, especially the environmental concerns, significantly affects stock returns, the cost of equity, and debt capital. Fernando et al. [10] show that only environment policies alleviating concerns increase shareholder value and no shareholder values are created by increasing firm greenness. The corporate bond risk premium is the compensation to the bondholders for not investing over risk-free 
assets. Following the stakeholder theory, if environmental management reduces firms' risk, the bondholders will require less risk premium for firms with better environment responsible performance. Thus, we expect that environmental management would benefit the firm in terms of the cost of debt.

Hypothesis 4 (H4). Corporate environmental performance is negatively associated with the cost of newly issued bond.

\section{Data, Sample, and Measures}

\subsection{Data and Sample}

We constructed our sample from various databases. We began with collecting the firmlevel CFO gender information from the Compustat Execucomp database, which includes most of U.S. S\&P 1500 public firms. Following Chava and Purnanandam [16] and Huang and Kisgen [20], we identified a firm's CFO by the 'CFOANN' variable. If there was no CFO found, we searched the executive title variable with specific keywords such as 'finance,' 'treasure,' or 'controller.' When there was still no CFO or more than one possible CFO for a firm, we manually checked the firm's 10-K filings from the Electronic Data Gathering, Analysis, and Retrieval system (EDGAR) at the U.S. Securities and Exchange Commission (SEC) to acquire correct CFO information. Next, we categorized CFO transitions by the gender of predecessor and successor. We applied the following requirements for any transitions to be included in our sample [20,49]. First, we required a CFO to be in the position for at least three years to exclude any temporary CFO turnovers. Second, the predecessor of transition must be male, and the successor is either male or female. Third, each firm was selected with one transition in our sample. That is, if a firm has conducted both male-to-female and male-to-male CFO transitions, we picked the male-to-female one since the major purpose of this study is to identify potential effects of female CFOs [18]. We kept the first change if there were multiple same-type transitions [19]. Fourth, financial and utility firms were excluded from the sample based on the SIC codes. We identified 94 male-to-female CFO transitions and 388 male-to-male CFO transitions between 2006 and 2015 in U.S. public firms. Table 1 presents the transition distribution by transition year and industry.

Table 1. Distribution of CFO transitions.

\begin{tabular}{ccc}
\hline & Panel A. By Transition Year & Male to Male \\
\hline Year & Male to Female & 65 \\
2006 & 8 & 48 \\
2007 & 12 & 47 \\
2008 & 8 & 30 \\
2009 & 3 & 34 \\
2010 & 3 & 36 \\
2011 & 13 & 35 \\
2012 & 15 & 27 \\
2013 & 8 & 39 \\
2014 & 13 & 27 \\
2015 & 11 & 388 \\
Total & 94 & 104 \\
& Panel B. By Fama-French 5 industries & Male to Male \\
\hline Industry & Male to Female & 107
\end{tabular}


Next, we matched the transition firms with the MSCI ESG KLD STATS (KLD) database for environmental management measures. KLD is the most widely used database to measure CSR as well as environmental management [9,10,50]. Our board-of-director measures are drawn from the ISS Directors database. We obtained firm financials and stock prices from Compustat and CRSP, respectively. We dropped any observations with missing variables and deleted any firms with only pre- or post-transition observations. Finally, our sample includes 4886 firm-year observations with 482 unique firms.

\subsection{Measures}

Our environmental management measures were obtained from the KLD database. KLD evaluates firms' CSR performance from multiple dimensions and we specifically focus on the environmental dimension. EM strength is the sum of firms' environmentally responsible activities and EM concern is the sum of firms' environmentally irresponsible activities. Consistent with previous literature, we scaled the count number by the number of maximum possible items in each year. EM net index measures the net environmental effect and equals the difference between EM strength and EM concern.

For executives other than CFOs, we controlled for whether a firm has a female CEO in a year (Female CEO). Execucomp provides information to up to nine executives for a company in a year. We then controlled for whether a firm has a female executive other than CFO or CEO (Other female executives dummy). In addition, the board of directors has been found to play critical roles in firms' CSR and environmental performance [51-54]. We included two variables to control the board size and female composition effects. Board size $(\log )$ is the natural logarithm of one plus the number of board members. Board gender diversity is the percentage of female board members of all board members.

Following prior studies [2,20], we included firm-level financial variables in our regressions to control for any firm characteristics effects. Firm size is the natural logarithm of the firm's asset. Book leverage is the sum of long-term and short-term debts divided by total assets. Profitability $(R O A)$ is the EBITDA scaled by total assets. RED intensity is the ratio of R\&D expense to the total assets. Number of segments $(\log )$ is the natural logarithm of one plus the number of firm segments. Market-to-book ratio is the market capitalization scaled by the book value of equity. Tangible assets is the net property, plant, and equipment value divided by total assets. We further included a dummy (financial crisis) to control for any market effects during the 2008 financial crisis [55-57]. We also counted the CFO tenure (Tenure) as the number of years a CFO is in the position [40]. Table 2 presents the summary statistics for our sample.

Table 2. Summary statistics.

\begin{tabular}{|c|c|c|c|c|c|c|c|c|}
\hline Variables & $\mathbf{N}$ & Mean & SD & Min & $\mathbf{P} 25$ & Median & P75 & $\operatorname{Max}$ \\
\hline EM net index & 4886 & 0.03 & 0.15 & -0.71 & 0.00 & 0.00 & 0.00 & 0.80 \\
\hline EM strength & 4886 & 0.06 & 0.14 & 0.00 & 0.00 & 0.00 & 0.00 & 0.80 \\
\hline EM concern & 4886 & 0.03 & 0.10 & 0.00 & 0.00 & 0.00 & 0.00 & 0.86 \\
\hline Post & 4886 & 0.48 & 0.50 & 0 & 0 & 0 & 1 & 1 \\
\hline Male-to-Female CFO & 4886 & 0.20 & 0.40 & 0 & 0 & 0 & 0 & 1 \\
\hline Female CEO & 4886 & 0.02 & 0.15 & 0 & 0 & 0 & 0 & 1 \\
\hline Other female executives dummy & 4886 & 0.25 & 0.43 & 0 & 0 & 0 & 1 & 1 \\
\hline Board size $(\log )$ & 4886 & 2.30 & 0.21 & 1.10 & 2.20 & 2.30 & 2.49 & 3.09 \\
\hline Board gender diversity & 4886 & 0.12 & 0.10 & 0.00 & 0.00 & 0.11 & 0.18 & 0.70 \\
\hline Firm size & 4886 & 7.89 & 1.51 & 4.82 & 6.73 & 7.78 & 8.87 & 12.01 \\
\hline Book leverage & 4886 & 0.21 & 0.18 & 0.00 & 0.06 & 0.20 & 0.32 & 0.78 \\
\hline Profitability (ROA) & 4886 & 0.15 & 0.08 & -0.17 & 0.10 & 0.14 & 0.19 & 0.41 \\
\hline R\&D intensity & 4886 & 0.03 & 0.05 & 0.00 & 0.00 & 0.00 & 0.03 & 0.27 \\
\hline Number of segments (log) & 4886 & 1.31 & 0.60 & 0.69 & 0.69 & 1.39 & 1.79 & 2.64 \\
\hline Market-to-book ratio & 4886 & 3.26 & 3.37 & -9.37 & 1.62 & 2.50 & 3.85 & 21.77 \\
\hline Tangible assets & 4886 & 0.25 & 0.21 & 0.01 & 0.09 & 0.19 & 0.34 & 0.88 \\
\hline Financial crisis & 4886 & 0.16 & 0.37 & 0 & 0 & 0 & 0 & 1 \\
\hline Tenure & 4886 & 3.86 & 2.68 & 1 & 2 & 3 & 5 & 19 \\
\hline Return volatility & 4877 & 0.02 & 0.01 & 0.01 & 0.02 & 0.02 & 0.03 & 0.08 \\
\hline FF beta & 4877 & 1.07 & 0.32 & 0.30 & 0.84 & 1.04 & 1.25 & 2.14 \\
\hline Idiosyncratic risk & 4877 & 0.61 & 0.79 & -1.07 & 0.05 & 0.57 & 1.13 & 2.96 \\
\hline
\end{tabular}




\section{Empirical Results \\ 4.1. Identification Strategy}

Potential endogeneity problems exist, as female CFOs are not assigned to firms randomly. Firms hiring female CFOs may be fundamentally different from those firms preferring male CFOs. Female executives may also have specific preferences on firm or industry, which indicates potential self-selection bias. Furthermore, there may exist omitted variables that influence the firms' choice on CFO gender and the environmental management decisions simultaneously. Following Huang and Kisgen [20] and others, we adopted a DID approach to mitigate those concerns by comparing the environment activities before and after male-to-female CFO transitions with a control sample of male-to-male CFO transitions. Comparing pre- and post-transition results helps to remove any time-invariant unobservable firm effects. The model is as follows:

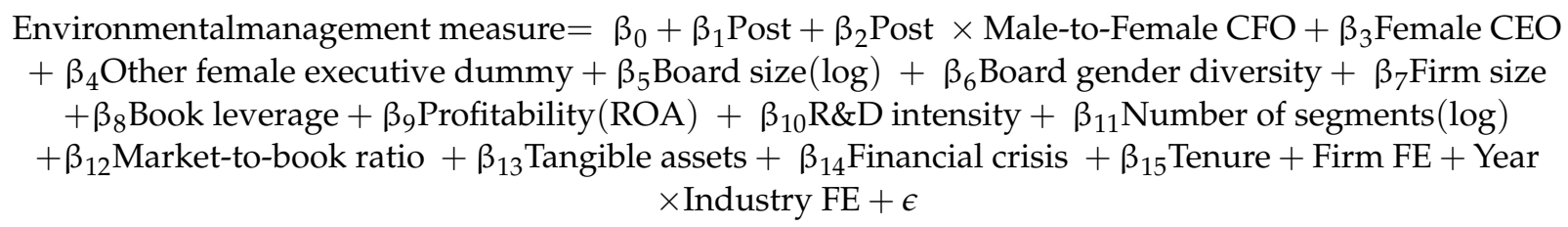

where Environmental management measure includes the EM net index, EM strength, and $E M$ concern we discussed previously. Post equals 1 if a year is post-transition and equals 0 if it is pre-transition. Male-to-Female CFO is a dummy variable that identifies our treatment group and the control group. Post $\times$ Male-to-female CFO is the interaction term from the DID design and is the variable of our interest. We include firm, year, and industry fixed effects in our regression. Regarding the coefficients, $\beta_{1}$ captures the difference in environment score before and after CFO transitions. $\beta_{2}$ is the coefficient of the main explanatory variable, which captures the DID effect of transiting to female CFOs on environment score comparing with transiting to male CFOs.

\subsection{Baseline Regression Results}

Table 3 presents the results of our baseline DID regression. In column 1 , our dependent variable is the net score of environmental management. The coefficient of the Post variable is insignificant, indicating that there is no significant difference before and after maleto-male CFO transitions. The effect of the treatment variable (Male-to-Female CFO) is absorbed in the firm fixed effects. The interaction term, the variable of our interest, shows a significantly positive coefficient. Holding other variables constant, firms with maleto-female CFO transitions demonstrate higher overall environmental performance after transitions comparing to those firms with male-to-male $\mathrm{CFO}$ transitions.

In column 2, we use EM strength as the dependent variable and the interaction term is positive and significant at $10 \%$ level. Given that the mean value of EM strength is 0.062 , female CFOs engage 39\% more environmentally responsible activities after transitions than male CFOs do. In column 3, we examine the effect of female CFOs on environmentally irresponsible activities. The dependent variable is EM concern and the coefficient is negative and significant at $10 \%$ level. After the transition, female CFOs reduce about $44 \%$ of environmentally irresponsible activities comparing to their male colleagues.

Our results support Hypothesis 1 and suggest that female CFOs are positively associated with overall environmentally responsible performance compared to male CFOs. Firms with female CFOs conduct more environmentally responsible activities and avoid environmentally irresponsible activities. 
Table 3. Difference-in-difference regression results.

\begin{tabular}{|c|c|c|c|}
\hline & (1) & (2) & (3) \\
\hline Variables & EM Net Index & EM Strength & EM Concern \\
\hline Post & $\begin{array}{c}-0.014 \\
(0.013)\end{array}$ & $\begin{array}{l}-0.006 \\
(0.011)\end{array}$ & $\begin{array}{c}0.008 \\
(0.005)\end{array}$ \\
\hline Post * Male-to-Female CFO & $\begin{array}{l}0.038^{* * *} \\
(0.016)\end{array}$ & $\begin{array}{l}0.024^{*} \\
(0.014)\end{array}$ & $\begin{array}{c}-0.015 \text { * } \\
(0.008)\end{array}$ \\
\hline Female CEO & $\begin{array}{l}-0.007 \\
(0.026)\end{array}$ & $\begin{array}{l}-0.003 \\
(0.016)\end{array}$ & $\begin{array}{c}0.004 \\
(0.018)\end{array}$ \\
\hline Other female executives dummy & $\begin{array}{c}0.010 \\
(0.011)\end{array}$ & $\begin{array}{c}0.002 \\
(0.008)\end{array}$ & $\begin{array}{l}-0.007 \\
(0.005)\end{array}$ \\
\hline Board size (log) & $\begin{array}{c}0.009 \\
(0.022)\end{array}$ & $\begin{array}{c}0.008 \\
(0.017)\end{array}$ & $\begin{array}{l}-0.001 \\
(0.012)\end{array}$ \\
\hline Board gender diversity & $\begin{array}{c}0.013 \\
(0.049)\end{array}$ & $\begin{array}{c}0.018 \\
(0.039)\end{array}$ & $\begin{array}{c}0.005 \\
(0.024)\end{array}$ \\
\hline Firm size & $\begin{array}{c}-0.024^{* * *} \\
(0.008)\end{array}$ & $\begin{array}{l}-0.005 \\
(0.006)\end{array}$ & $\begin{array}{c}0.019^{* * *} \\
(0.005)\end{array}$ \\
\hline Book leverage & $\begin{array}{c}0.051 \text { ** } \\
(0.024)\end{array}$ & $\begin{array}{c}0.043^{* *} \\
(0.021)\end{array}$ & $\begin{array}{l}-0.008 \\
(0.012)\end{array}$ \\
\hline Profitability (ROA) & $\begin{array}{c}0.004 \\
(0.042)\end{array}$ & $\begin{array}{c}0.015 \\
(0.035)\end{array}$ & $\begin{array}{c}0.011 \\
(0.019)\end{array}$ \\
\hline R\&D intensity & $\begin{array}{c}-0.249^{* *} \\
(0.120)\end{array}$ & $\begin{array}{l}-0.161 \\
(0.106)\end{array}$ & $\begin{array}{c}0.088^{* *} \\
(0.042)\end{array}$ \\
\hline Number of segments (log) & $\begin{array}{c}0.001 \\
(0.009)\end{array}$ & $\begin{array}{l}-0.001 \\
(0.008)\end{array}$ & $\begin{array}{l}-0.002 \\
(0.004)\end{array}$ \\
\hline Market-to-book ratio & $\begin{array}{c}0.000 \\
(0.001)\end{array}$ & $\begin{array}{c}0.000 \\
(0.001)\end{array}$ & $\begin{array}{l}-0.000 \\
(0.000)\end{array}$ \\
\hline Tangible assets & $\begin{array}{c}-0.132^{* * *} \\
(0.047)\end{array}$ & $\begin{array}{c}-0.129^{* * *} \\
(0.039)\end{array}$ & $\begin{array}{c}0.003 \\
(0.030)\end{array}$ \\
\hline Financial crisis & $\begin{array}{l}0.182 * \\
(0.107)\end{array}$ & $\begin{array}{c}0.123^{* *} \\
(0.051)\end{array}$ & $\begin{array}{l}-0.059 \\
(0.061)\end{array}$ \\
\hline Tenure & $\begin{array}{l}-0.000 \\
(0.002)\end{array}$ & $\begin{array}{l}-0.000 \\
(0.002)\end{array}$ & $\begin{array}{c}0.000 \\
(0.001)\end{array}$ \\
\hline Constant & $\begin{array}{c}0.090 \\
(0.070)\end{array}$ & $\begin{array}{c}0.028 \\
(0.055)\end{array}$ & $\begin{array}{l}-0.062 \\
(0.041)\end{array}$ \\
\hline Observations & 4886 & 4886 & 4886 \\
\hline R-squared & 0.204 & 0.196 & 0.153 \\
\hline
\end{tabular}

Note: Standard errors are clustered at the firm level. ${ }^{* * *} p<0.01,{ }^{* *} p<0.05,{ }^{*} p<0.1$.

We conducted a placebo test on our sample by assigning a fake transition year. Specifically, we kept observations of each firm before the real transition year $t$ and assign the $t-3$ year as an assumed transition year. Those after $\mathrm{t}-3$ years are labeled as new post years. We expect to observe insignificant interaction terms. Otherwise, our previous findings may be biased by potential pre-transition trends of environmental social activities. We reran our DID regression with the same control variables and model setting. For brevity, we only report the interaction terms in Table 4 . In line with our expectations, none of the three interaction terms are significant.

Table 4. Placebo tests regression results.

\begin{tabular}{cccc}
\hline & $\mathbf{( 1 )}$ & $\mathbf{( 2 )}$ & $\mathbf{( 3 )}$ \\
\hline Variables & EM Net Index & EM Strength & EM Concern \\
\hline Post (Placebo) $\times$ Male-to-Female CFO & 0.027 & 0.021 & -0.006 \\
& $(0.019)$ & $(0.016)$ & $(0.009)$ \\
Board Characteristics & Yes & Yes & Yes \\
Executive Characteristics & Yes & Yes & Yes \\
Firm Characteristics & Yes & Yes & Yes \\
Firm FE & Yes & Yes & 2523 \\
Year $\times$ Industry FE & Yes & 2523 & 0.138 \\
Observations & 2523 & 0.218 & \\
R-squared & 0.226 & & \\
\hline
\end{tabular}

Note: Standard errors are clustered at the firm level. ${ }^{* *} p<0.05,{ }^{*} p<0.1$. 
In addition, we examined whether there is any change when a female CFO is replaced by a male CFO as a further robustness test. If female CFOs tend to conduct more (less) environment responsible (irresponsible) activities, we expect to see the opposite or no difference when a female CFO is replaced by a male CFO. We identified 60 female-to-male CFO transitions applying the same requirements during the same transition period as our main sample. Then we ran firm fixed effect regressions on male-to-female CFO transition firms. Table 5 presents the regression results. The dependent variables are EM net score, strength, and concerns respectively. Post is a dummy variable, which equals 1 if it is a post-transition year and 0 otherwise. We found a significant negative coefficient on post when the dependent variable was the EM net score and significantly positive coefficients when the dependent variable was the environmental concerns. These results indicate that male CFOs tend to undertake more environmentally irresponsible activities while showing no incentives for improving environmentally responsible activities. This result triangulates Hypothesis 1 that female CFOs pay more attention to environmental management.

Table 5. Female-to-male transition regression results.

\begin{tabular}{cccc}
\hline & $\mathbf{( 1 )}$ & $\mathbf{( 2 )}$ & $\mathbf{( 3 )}$ \\
\hline Variables & EM Net Index & EM Strength & EM Concern \\
\hline Post & $-0.082^{* *}$ & -0.043 & $0.040^{* *}$ \\
& $(0.037)$ & $(0.027)$ & $(0.019)$ \\
Board Characteristics & Yes & Yes & Yes \\
Executive Characteristics & Yes & Yes & Yes \\
Firm Characteristics & Yes & Yes & Yes \\
Firm FE & Yes & Yes & Yes \\
Year ${ }^{*}$ Industry FE & Yes & Yes & Yes \\
Observations & 580 & 580 & 580 \\
R-squared & 0.309 & 0.328 & 0.427 \\
\hline
\end{tabular}

Note: Standard errors are clustered at the firm level. ${ }^{* *} p<0.05,{ }^{*} p<0.1$.

\subsection{Female CFOs, Environmental Management, and Firm Risks}

Following Hypothesis 2, one of the reasons that female CFOs emphasize environmental management more is due to their risk aversions. Hence, when a firm has high risks before the transition, we expected that the previously found effects would be prominent as the female CFOs would be more likely to take action to reduce environmental risks. In this section, we construct subsamples by multilevel risk measures and compare the DID results.

Our first risk measure is total risks based on the daily return volatility. We first calculated the standard deviation of daily stock returns for each firm in each year. Then we categorized a firm as high (low) total risk if its total risks measure is above (below) the median in the year prior to the transition year. For the second risk measure, we evaluated the firm's systematic risks using the beta from the Fama-French (FF) three-factor model with a momentum factor $[58,59]$. The Fama-French four-factor model has been considered as a better estimate for stock returns than the CAPM model $[60,61]$ (Using CAPM model beta does not change our results materially). We regressed firms' return on the market risk factor, book-to-market factor, size factor, and momentum factor using daily data. The factor data were collected from Kenneth R. French's website. (https:/ / mba.tuck.dartmouth.edu/ pages/faculty/ken.french/Data_Library/f-f_factors.html, 23 March 2021) We classified a firm as a high (low) systematic risk firm if its regression beta on market risk factor was greater (less) than 1 because the market risk has a beta equal to 1 . Third, we measured firms' idiosyncratic risk as suggested by Luo and Bhattacharya [61]. Specifically, we first obtained the R-square $\left(R^{2}\right)$ from the Fama-French four-factor regressions that we used to estimate the systematic risks. The ratio of idiosyncratic risks to the total risks was then calculated as $1-R^{2}$. Next, we performed a logistic transformation to obtain the final measure of firm idiosyncratic risk. Firms were classified to high (low) idiosyncratic risk firms if they have above (below) median measure before the CFO transitions. Our final measure of firm risk 
is firm leverage. High leverage firms generally face more financial risks and are sensitive to financial shocks. Similar to the previous approach, firms were split into subgroups by the relationship between pre-transition year leverage and the median leverage.

Table 6 presents the results of the subsample regression results. The first three columns show the regression results for firms with high risks before $\mathrm{CFO}$ transition and the last three columns show the results for firms with low risks before CFO transition. Consistent with Hypothesis 2, female CFOs from high-risk firms conduct more overall environmentally responsible activities while female CFOs from low-risk firms show barely any difference after transitions. From the perspective of strengths and concerns, female CFOs in high-risk firms pay more attention to reducing environmentally irresponsible activities.

Table 6. Female CFO, environment CSR, and firm risks.

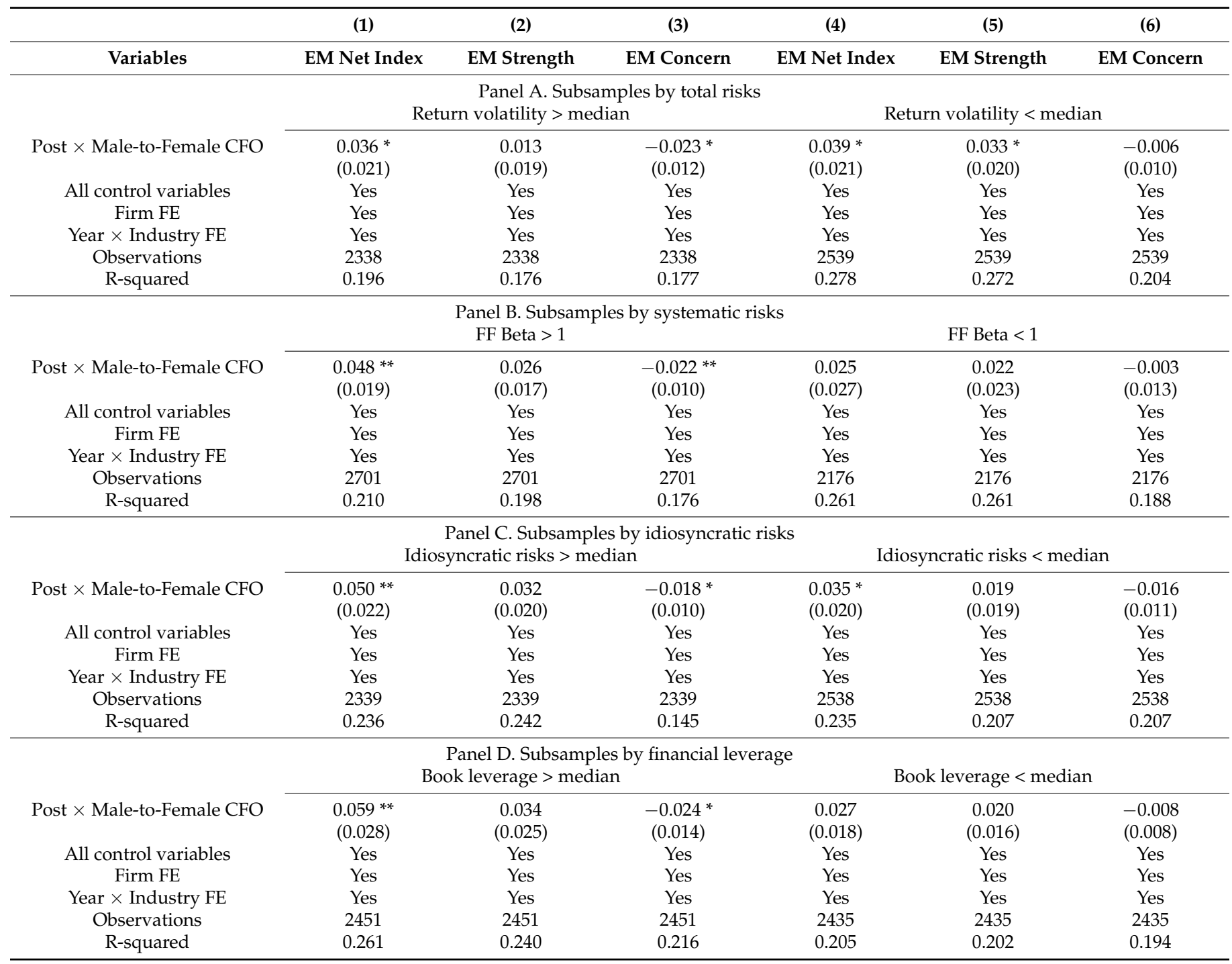

Note: This table presents the results of the DID setting in Table 3 for subsamples. For brevity, only the interaction terms are reported. Standard errors are clustered at the firm level. ${ }^{* *} p<0.05,{ }^{*} p<0.1$.

\subsection{Female CFOs, Environmental Management, and Stakeholder Values}

To test Hypothesis 3, we adopted an exogenous shock to exam the potential impact of female CFO's attention on nonfinancial stakeholders. Specifically, we used the passage of constituency statutes as a quasi-natural experiment, the statutes of which require corporate directors to consider stakeholders' interests when making business decisions. The constituency statutes have been passed in different states gradually since 1984. We divided our 
sample based on whether constituency statutes are passed at the firm incorporating state when $\mathrm{CFO}$ transition occurs. If the female CFOs pay more attention to the environment and other nonfinancial stakeholders, we expected to see a stronger change of environmental management in those firms incorporated in states without the passage of constituency statutes. In such a situation, female CFOs choose to conduct more environmental management and male CFOs are not necessarily conduct similar policies. On the contrary, if the incorporating states have already passed the constituency statutes, we expect to see no significant difference between male and female CFOs and pre- and post-transitions, as male CFOs are also required to take care of all the stakeholders. We test this hypothesis and show our results in Table 7. In the first three columns, we rerun our baseline regression for the firms of which the incorporation states have passed the statutes prior to the transition and in the last three columns we report the results for those firms without the requirements by the constituency statutes. Consistent with our Hypothesis 3, female CFOs tend to voluntarily engage in environmental management when they are not required to do so.

Table 7. Female CFO, environment CSR, and stakeholder orientation.

\begin{tabular}{|c|c|c|c|c|c|c|}
\hline & (1) & (2) & (3) & (4) & (5) & (6) \\
\hline \multirow[t]{2}{*}{ Variables } & EM Net Index & EM Strength & EM Concern & EM Net Index & EM Strength & EM Concern \\
\hline & \multicolumn{3}{|c|}{ State with Constituency Statute } & \multicolumn{3}{|c|}{ State without Constituency Statute } \\
\hline Post $\times$ Male-to-Female CFO & 0.008 & 0.016 & 0.008 & $0.058 * * *$ & $0.034 * *$ & $-0.024^{* *}$ \\
\hline & $(0.028)$ & $(0.027)$ & $(0.010)$ & $(0.018)$ & $(0.016)$ & $(0.010)$ \\
\hline All control variables & Yes & Yes & Yes & Yes & Yes & Yes \\
\hline Firm FE & Yes & Yes & Yes & Yes & Yes & Yes \\
\hline Year $\times$ Industry FE & Yes & Yes & Yes & Yes & Yes & Yes \\
\hline Observations & 1425 & 1425 & 1425 & 3452 & 3452 & 3452 \\
\hline R-squared & 0.219 & 0.224 & 0.266 & 0.238 & 0.230 & 0.154 \\
\hline
\end{tabular}

Note: This table presents the results of the DID setting in Table 3 for subsamples. For brevity, only the interaction terms are reported. Standard errors are clustered at the firm level. ${ }^{* * *} p<0.01,{ }^{* *} p<0.05,{ }^{*} p<0.1$.

\subsection{Environmental Management and Cost of Newly Issued Bonds}

In this section, we examine Hypothesis 4, which is whether better environmental management reduces firms' cost of newly issued bonds. We matched firms in our sample with SDC Platinum Global New Issues Database for the corporate bond information. Following Qi, Roth, and Wald [62] and Liu, Ning, and Davidson [63], we constructed two measures of the cost of bonds. The first measure is the yield spread at the time of issue, which is the difference between the yield-to-maturity of the bond and a durationequivalent risk-free bond. When a firm issues multiple bonds within a year, the yield spread is averaged using the bond proceedings as the weights. Our second measure is the bond credit rating by S\&P. Following conventions, we recoded the credit ratings from letters to numbers between 21 (AAA) and 1 (C).

Table 8 reports the OLS regression results. In the first two columns, the dependent variables are the natural logarithm of the yield spread. Consistent with the stakeholder theory, we found that EM net index is negatively related to the yield spread and the relation is significant at $1 \%$ level. The firm's overall environmental performance indeed reduces the bond yield spread. When substituting the net index with EM strength and EM concern, we found that bondholders pay attention to the firm's environmentally responsible performance over irresponsible activities. In the last two columns of Table 8, we use credit rating as the ex-ante cost of bond. The results are similar: firms with better environmental management are associated with higher credit ratings and the positive effect is mainly from environmentally responsible activities. 
Table 8. Environmental management and cost of newly issued debt.

\begin{tabular}{|c|c|c|c|c|}
\hline & (1) & (2) & (3) & (4) \\
\hline Variables & Yield Spread (log) & Yield Spread (log) & S\&P Credit Rating & S\&P Credit Rating \\
\hline EM net index & $\begin{array}{c}-0.222 \text { ** } \\
(0.094)\end{array}$ & & $\begin{array}{l}1.144^{* *} \\
(0.567)\end{array}$ & \\
\hline EM strength & & $\begin{array}{c}-0.205^{* *} \\
(0.100)\end{array}$ & & $\begin{array}{c}2.292 * * * \\
(0.700)\end{array}$ \\
\hline EM concern & & $\begin{array}{c}0.253 \\
(0.179)\end{array}$ & & $\begin{array}{c}1.019 \\
(1.000)\end{array}$ \\
\hline Firm size & $\begin{array}{c}-0.108^{* * *} \\
(0.023)\end{array}$ & $\begin{array}{c}-0.110^{* * *} \\
(0.022)\end{array}$ & $\begin{array}{c}1.535^{* * *} \\
(0.141)\end{array}$ & $\begin{array}{c}1.370 * * * \\
(0.150)\end{array}$ \\
\hline Book leverage & $\begin{array}{c}0.054 \\
(0.156)\end{array}$ & $\begin{array}{c}0.053 \\
(0.155)\end{array}$ & $\begin{array}{c}-5.003^{* * * *} \\
(0.944)\end{array}$ & $\begin{array}{c}-4.985^{* * *} \\
(0.921)\end{array}$ \\
\hline Profitability (ROA) & $\begin{array}{c}-0.801^{* * *} \\
(0.252)\end{array}$ & $\begin{array}{c}-0.799^{* * *} \\
(0.251)\end{array}$ & $\begin{array}{c}14.408^{* * *} \\
(1.956)\end{array}$ & $\begin{array}{c}14.214^{* * *} \\
(1.934)\end{array}$ \\
\hline R\&D intensity & $\begin{array}{l}-0.005 \\
(0.436)\end{array}$ & $\begin{array}{l}-0.033 \\
(0.435)\end{array}$ & $\begin{array}{c}3.553 \\
(3.242)\end{array}$ & $\begin{array}{c}1.486 \\
(3.246)\end{array}$ \\
\hline Number of segments (log) & $\begin{array}{c}0.024 \\
(0.031)\end{array}$ & $\begin{array}{c}0.023 \\
(0.031)\end{array}$ & $\begin{array}{c}0.314 \\
(0.250)\end{array}$ & $\begin{array}{c}0.239 \\
(0.253)\end{array}$ \\
\hline Market-to-book ratio & $\begin{array}{l}-0.006 \\
(0.004)\end{array}$ & $\begin{array}{l}-0.006 \\
(0.004)\end{array}$ & $\begin{array}{c}0.053 \\
(0.035)\end{array}$ & $\begin{array}{c}0.053 \\
(0.033)\end{array}$ \\
\hline Tangible assets & $\begin{array}{c}0.134 \\
(0.092)\end{array}$ & $\begin{array}{c}0.133 \\
(0.092)\end{array}$ & $\begin{array}{c}-1.591^{* *} \\
(0.689)\end{array}$ & $\begin{array}{c}-1.639^{* *} \\
(0.664)\end{array}$ \\
\hline Financial crisis & $\begin{array}{c}1.425^{* * * *} \\
(0.200)\end{array}$ & $\begin{array}{c}1.430 * * * \\
(0.205)\end{array}$ & $\begin{array}{l}-1.656 \\
(1.273)\end{array}$ & $\begin{array}{l}-1.292 \\
(1.360)\end{array}$ \\
\hline Bond proceeds (log) & $\begin{array}{c}0.085^{* * *} \\
(0.021)\end{array}$ & $\begin{array}{c}0.085^{* * *} \\
(0.021)\end{array}$ & $\begin{array}{c}0.065 \\
(0.177)\end{array}$ & $\begin{array}{c}0.076 \\
(0.175)\end{array}$ \\
\hline Bond maturity (log) & $\begin{array}{c}0.117^{* * *} \\
(0.040)\end{array}$ & $\begin{array}{c}0.117^{* * *} \\
(0.040)\end{array}$ & $\begin{array}{l}-0.122 \\
(0.231)\end{array}$ & $\begin{array}{l}-0.138 \\
(0.235)\end{array}$ \\
\hline S\&P credit rating & $\begin{array}{c}-0.144^{* * *} \\
(0.008)\end{array}$ & $\begin{array}{c}-0.145^{* * *} \\
(0.008)\end{array}$ & & \\
\hline Constant & $\begin{array}{c}6.431^{* * *} \\
(0.274)\end{array}$ & $\begin{array}{c}6.444^{* * *} \\
(0.266)\end{array}$ & $\begin{array}{l}-0.118 \\
(1.708)\end{array}$ & $\begin{array}{c}0.784 \\
(1.813)\end{array}$ \\
\hline Year FE & Yes & Yes & Yes & Yes \\
\hline Industry FE & Yes & Yes & Yes & Yes \\
\hline Observations & 803 & 803 & 803 & 803 \\
\hline R-squared & 0.778 & 0.778 & 0.655 & 0.663 \\
\hline
\end{tabular}

Note: Standard errors are clustered at the firm level. ${ }^{* * *} p<0.01,{ }^{* *} p<0.05,{ }^{*} p<0.1$.

\section{Conclusions}

In this paper, we investigate how executive gender influences firm environmental management. Based on the upper echelon theory, we built the hypotheses that female CFOs' personality and characteristics are critical to a firm's environmental responsibility performance. Specifically, female CFOs' risk aversion, ethicality, and closeness to the environment and stakeholders could lead female CFOs to pay more attention to the green strategy. We found evidence supporting our hypotheses. Female CFOs tend to conduct more environmentally responsible activities and reduce irresponsible activities. Our findings shed new light on the determinants of green management and gender difference literature.

We acknowledge that scholars have investigated the relation between gender diversity in top management and corporate environmental performance. Previous studies document that corporate environment investment and corporate social responsibility are significantly associated with gender diversity in the boardroom [64-66] and the CEO gender $[67,68]$. Our work differs from theirs in several aspects. We focused on the increasing role of CFOs that is often neglected by scholars previously. We further adopted DID regression settings that mitigate potential endogeneity concerns. We also provide evidence on the benefits of 
environmental management. Firms with a better environment responsible performance tend to save costs of newly issued bonds and be rated higher by the credit rating agency.

We recognize that our study is not without limitations. For example, the impacts of female CFOs on corporate environmental management are drawn from data from the U.S. market. Our findings may not be able to generalize to other markets. For another instance, in our model we control for the female presence in the board and top executives. Nonetheless, we do not control for the gender diversity of rank-and-file employees due to data limitations. We assume that ordinary employees have less impact on the decision-making of environmental management strategy than the board of directors and top executives based on their different job functions. In most cases, directors and executives are in charge of determining firm strategies and ordinary employees are only responsible for executing those decisions. Furthermore, empirical evidence suggests a reverse direction in which CSR and corporate environmental performance plays a critical role in attracting and retaining ordinary employees $[69,70]$.

Despite the above-mentioned possible limitations, we believe that our contributions are multifold. First, we extend the green management literature by linking the effect of executive gender differences on environmental responsibility performance. Previous literature recognizes multiple factors that influence firms' decisions on corporate environmental and social responsibility practices, such as the board of director composition [54] and institutional investors [50]. However, there is less known about how executives' managerial traits drive the firm environmental policy. Our work helps to fill the gap between executive demographics and the firm's environmental practices. Second, we advance the gender diversity literature and provide evidence on how the risk preference built in the executive gender influences corporate strategy and decision-making. Specifically, we show that female CFOs' risk aversion plays a critical role in environmental management, as female CFOs in high-risk firms tend to pay more attention to environmental management. Third, we extend the stakeholder value maximization theory and find that the female executive voluntarily pays more attention to the stakeholders. Lastly, we provide new evidence on the benefits of green management, which is that female CFOs' concern to environmental management leads to cost savings on newly issued corporate bonds.

Author Contributions: Conceptualization, B.W., Z.W., J.W., and X.T.Z.; methodology, B.W., Z.W., J.W., and X.T.Z.; analysis, B.W.; writing-original draft preparation: B.W. and X.T.Z.; writing-review and editing: Z.W., J.W. All authors have read and agreed to the published version of the manuscript.

Funding: This research received no external funding.

Institutional Review Board Statement: Not applicable.

Informed Consent Statement: Not applicable.

Data Availability Statement: No new data were created or analyzed in this study. Data sharing is not applicable to this article.

Conflicts of Interest: The authors declare no conflict of interest.

\section{References}

1. Lyon, T.P.; Maxwell, J.W. Corporate social responsibility and the environment: A theoretical perspective. Rev. Environ. Econ. Policy 2008, 2, 240-260. [CrossRef]

2. Chava, S. Environmental externalities and cost of capital. Manag. Sci. 2014, 60, 2223-2247. [CrossRef]

3. Heinkel, R.; Kraus, A.; Zechner, J. The effect of green investment on corporate behavior. J. Financ. Quant. Anal. 2001, 36, 431-449. [CrossRef]

4. Gilley, K.M.; Worrell, D.L.; Davidson, W.N., III; El-Jelly, A. Corporate environmental initiatives and anticipated firm performance: The differential effects of process-driven versus product-driven greening initiatives. J. Manag. 2000, 26, 1199-1216. [CrossRef]

5. Judge, W.Q.; Douglas, T.J. Performance implications of incorporating natural environmental issues into the strategic planning process: An empirical assessment. J. Manag. Stud. 1998, 35, 241-262. [CrossRef]

6. King, A.A.; Lenox, M.J. Does it really pay to be green? An empirical study of firm environmental and financial performance: An empirical study of firm environmental and financial performance. J. Ind. Ecol. 2001, 5, 105-116. [CrossRef]

7. Bansal, P.; Roth, K. Why companies go green: A model of ecological responsiveness. Acad. Manag. J. 2000, 43, 717-736. 
8. Jin, D.; Liu, L.; Ma, J.; Wang, H.; Yin, D. How Have Green Companies Fared in Transactions with Banks? A StakeholderManagement Perspective. J. Appl. Corp. Financ. 2018, 30, 89-107.

9. Sharfman, M.P.; Fernando, C.S. Environmental risk management and the cost of capital. Strateg. Manag. J. 2008, $29,569-592$. [CrossRef]

10. Fernando, C.S.; Sharfman, M.P.; Uysal, V.B. Corporate environmental policy and shareholder value: Following the smart money. J. Financ. Quant. Anal. 2017, 52, 2023-2051. [CrossRef]

11. Hart, S.L. A natural-resource-based view of the firm. Acad. Manag. Rev. 1995, 20, 986-1014. [CrossRef]

12. Shrivastava, P. Environmental technologies and competitive advantage. Strateg. Manag. J. 1995, 16, 183-200. [CrossRef]

13. Benmelech, E.; Frydman, C. Military CEOs. J. Financ. Econ. 2015, 117, 43-59. [CrossRef]

14. Bertrand, M.; Schoar, A. Managing with style: The effect of managers on firm policies. Q. J. Econ. 2003, 118, 1169-1208. [CrossRef]

15. Lewis, B.W.; Walls, J.L.; Dowell, G.W. Difference in degrees: CEO characteristics and firm environmental disclosure. Strateg. Manag. J. 2014, 35, 712-722. [CrossRef]

16. Chava, S.; Purnanandam, A. CEOs versus CFOs: Incentives and corporate policies. J. Financ. Econ. 2010, 97, 263-278. [CrossRef]

17. Jiang, J.X.; Petroni, K.R.; Wang, I.Y. CFOs and CEOs: Who have the most influence on earnings management? J. Financ. Econ. 2010, 96, 513-526. [CrossRef]

18. Faccio, M.; Marchica, M.-T.; Mura, R. CEO gender, corporate risk-taking, and the efficiency of capital allocation. J. Corp. Financ. 2016, 39, 193-209. [CrossRef]

19. Francis, B.B.; Hasan, I.; Wu, Q.; Yan, M. Are female CFOs less tax aggressive? Evidence from tax aggressiveness. J. Am. Tax. Assoc. 2014, 36, 171-202. [CrossRef]

20. Huang, J.; Kisgen, D.J. Gender and corporate finance: Are male executives overconfident relative to female executives? J. Financ. Econ. 2013, 108, 822-839. [CrossRef]

21. Croson, R.; Gneezy, U. Gender differences in preferences. J. Econ. Lit. 2009, 47, 448-474. [CrossRef]

22. Eckel, C.C.; Grossman, P.J. Men, women and risk aversion: Experimental evidence. Handb. Exp. Econ. Results 2008, 1, 1061-1073.

23. Hambrick, D.C. Upper Echelons Theory: An Update. Acad. Manag. Rev. 2007, 32, 334-343. [CrossRef]

24. Hambrick, D.C.; Mason, P.A. Upper echelons: The organization as a reflection of its top managers. Acad. Manag. Rev. 1984, 9, 193-206. [CrossRef]

25. Ford, R.C.; Richardson, W.D. Ethical decision making: A review of the empirical literature. J. Bus. Ethics 1994, 13, $205-221$. [CrossRef]

26. Ibrahim, N.; Angelidis, J.; Tomic, I.M. Managers' attitudes toward codes of ethics: Are there gender differences? J. Bus. Ethics 2009, 90, 343-353. [CrossRef]

27. Wehrmeyer, W.; McNeil, M. Activists, pragmatists, technophiles and tree-huggers? Gender differences in employees' environmental attitudes. J. Bus. Ethics 2000, 28, 211-222. [CrossRef]

28. Davidson, D.J.; Freudenburg, W.R. Gender and environmental risk concerns: A review and analysis of available research. Environ. Behav. 1996, 28, 302-339. [CrossRef]

29. Diamantopoulos, A.; Schlegelmilch, B.B.; Sinkovics, R.R.; Bohlen, G.M. Can socio-demographics still play a role in profiling green consumers? A review of the evidence and an empirical investigation. J. Bus. Res. 2003, 56, 465-480. [CrossRef]

30. Freeman, R.E. Strategic Management: A Stakeholder Approach; Cambridge University Press: Cambridge, UK, 2010.

31. Freeman, R.E.; Wicks, A.C.; Parmar, B. Stakeholder theory and "the corporate objective revisited". Organ. Sci. 2004, 15, 364-369. [CrossRef]

32. Malmendier, U.; Tate, G. CEO overconfidence and corporate investment. J. Financ. 2005, 60, 2661-2700. [CrossRef]

33. Malmendier, U.; Tate, G.; Yan, J. Overconfidence and early-life experiences: The effect of managerial traits on corporate financial policies. J. Financ. 2011, 66, 1687-1733. [CrossRef]

34. Cumming, D.; Leung, T.Y.; Rui, O. Gender diversity and securities fraud. Acad. Manag. J. 2015, 58, 1572-1593. [CrossRef]

35. Manner, M.H. The impact of CEO characteristics on corporate social performance. J. Bus. Ethics 2010, 93, 53-72. [CrossRef]

36. Peni, E.; Vähämaa, S. Female executives and earnings management. Manag. Financ. 2010, 36, 629-645.

37. Bernasek, A.; Shwiff, S. Gender, risk, and retirement. J. Econ. Issues 2001, 35, 345-356. [CrossRef]

38. Sunden, A.E.; Surette, B.J. Gender differences in the allocation of assets in retirement savings plans. Am. Econ. Rev. 1998, 88, 207-211.

39. Olsen, R.A.; Cox, C.M. The influence of gender on the perception and response to investment risk: The case of professional investors. J. Psychol. Financ. Mark. 2001, 2, 29-36. [CrossRef]

40. Li, Y.; Zeng, Y. The impact of top executive gender on asset prices: Evidence from stock price crash risk. J. Corp. Financ. 2019, 58, 528-550. [CrossRef]

41. Dawson, L.M. Ethical differences between men and women in the sales profession. J. Bus. Ethics 1997, 16, 1143-1152. [CrossRef]

42. Mason, E.S.; Mudrack, P.E. Gender and ethical orientation: A test of gender and occupational socialization theories. J. Bus. Ethics 1996, 15, 599-604. [CrossRef]

43. Xia, H.; Tan, Q.; Bai, J. Corruption and Technological Innovation in Private Small-Medium Scale Companies: Does Female Top Management Play a Role? Sustainability 2018, 10, 2252. [CrossRef]

44. Bord, R.J.; O'Connor, R.E. The gender gap in environmental attitudes: The case of perceived vulnerability to risk. Soc. Sci. Q. $1997,78,830-840$. 
45. Stanny, E.; Ely, K. Corporate environmental disclosures about the effects of climate change. Corp. Soc. Responsib. Environ. Manag. 2008, 15, 338-348. [CrossRef]

46. Eccles, R.G.; Serafeim, G.; Krzus, M.P. Market interest in nonfinancial information. J. Appl. Corp. Financ. 2011, $23,113-127$. [CrossRef]

47. Ioannou, I.; Serafeim, G. The impact of corporate social responsibility on investment recommendations: Analysts' perceptions and shifting institutional logics. Strateg. Manag. J. 2015, 36, 1053-1081. [CrossRef]

48. Nielsen, S.; Huse, M. The contribution of women on boards of directors: Going beyond the surface. Corp. Gov. Int. Rev. 2010, 18, 136-148. [CrossRef]

49. Francis, B.; Hasan, I.; Park, J.C.; Wu, Q. Gender differences in financial reporting decision making: Evidence from accounting conservatism. Contemp. Account. Res. 2015, 32, 1285-1318. [CrossRef]

50. Graves, S.B.; Waddock, S.A. Institutional owners and corporate social performance. Acad. Manag. J. 1994, 37, $1034-1046$.

51. Bear, S.; Rahman, N.; Post, C. The impact of board diversity and gender composition on corporate social responsibility and firm reputation. J. Bus. Ethics 2010, 97, 207-221. [CrossRef]

52. Boulouta, I. Hidden connections: The link between board gender diversity and corporate social performance. J. Bus. Ethics 2013, 113, 185-197. [CrossRef]

53. Harjoto, M.; Laksmana, I.; Lee, R. Board diversity and corporate social responsibility. J. Bus. Ethics 2015, 132, 641-660. [CrossRef]

54. Post, C.; Rahman, N.; Rubow, E. Green governance: Boards of directors' composition and environmental corporate social responsibility. Bus. Soc. 2011, 50, 189-223. [CrossRef]

55. Klapper, L.; Love, I. The impact of the financial crisis on new firm registration. Econ. Lett. 2011, 113, 1-4. [CrossRef]

56. Kontonikas, A.; Macdonald, R.; Saggu, A. Stock market reaction to fed funds rate surprises: State dependence and the financial crisis. J. Bank. Financ. 2013, 37, 4025-4037. [CrossRef]

57. Lins, K.; Servaes, H.; Tamayo, A. Social capital, trust, and firm performance: The value of corporate social responsibility during the financial crisis. J. Financ 2017, 72, 1785-1823. [CrossRef]

58. Fama, E.F.; French, K.R. Multifactor explanations of asset pricing anomalies. J. Financ. 1996, 51, 55-84. [CrossRef]

59. Carhart, M.M. On persistence in mutual fund performance. J. Financ. 1997, 52, 57-82. [CrossRef]

60. Fama, E.F.; French, K.R. The value premium and the CAPM. J. Financ. 2006, 61, 2163-2185. [CrossRef]

61. Luo, X.; Bhattacharya, C.B. The debate over doing good: Corporate social performance, strategic marketing levers, and firmidiosyncratic risk. J. Mark. 2009, 73, 198-213. [CrossRef]

62. Qi, Y.; Roth, L.; Wald, J.K. Political rights and the cost of debt. J. Financ. Econ. 2010, 95, 202-226. [CrossRef]

63. Liu, Y.; Ning, Y.; Davidson, W.N., III. Earnings management surrounding new debt issues. Financ. Rev. 2010, 45, 659-681. [CrossRef]

64. Hyun, E.; Yang, D.; Jung, H.; Hong, K. Women on Boards and Corporate Social Responsibility. Sustainability 2016, 8, 300. [CrossRef]

65. Wei, F.; Ding, B.; Kong, Y. Female Directors and Corporate Social Responsibility: Evidence from the Environmental Investment of Chinese Listed Companies. Sustainability 2017, 9, 2292. [CrossRef]

66. Hu, L.; Yang, D. Female Board Directors and Corporate Environmental Investment: A Contingent View. Sustainability 2021, 13, 1975. [CrossRef]

67. Jiang, X.; Akbar, A. Does Increased Representation of Female Executives Improve Corporate Environmental Investment? Evidence from China. Sustainability 2018, 10, 4750. [CrossRef]

68. Vacca, A.; Iazzi, A.; Vrontis, D.; Fait, M. The Role of Gender Diversity on Tax Aggressiveness and Corporate Social Responsibility: Evidence from Italian Listed Companies. Sustainability 2020, 12, 2007. [CrossRef]

69. Turban, D.B.; Greening, D.W. Corporate Social Performance And Organizational Attractiveness To Prospective Employees. Acad. Manag. J. 1997, 40, 658-672.

70. Bode, C.; Singh, J.; Rogan, M. Corporate Social Initiatives and Employee Retention. Organ. Sci. 2015, 26, 1702-1720. [CrossRef] 